\title{
Excretion of biliary fat and fatty acids in growing pigs
}

\author{
H. Jørgensen, K. Jakobsen and B. O. Eggum \\ National Institute of Animal Science \\ Research Centre Foulum, P.O. Box 39, DK-8830 Tjele, Denmark
}

(Received 18 August 1992; accepted 21 September 1992)

\begin{abstract}
The aim of the present work was to study the contribution of bile secretion to endogenous excretion with special emphasis on the amount of fat and long chain fatty acids. A cannulation technique with a re-entrant cannulae via a duodenal pouch was developed for the purpose. With three growing pigs of $30 \mathrm{~kg}$ initial live weight several collections of bile were carried out over $24 \mathrm{hr}$ periods. The average daily bile output was 1.81 , but with high variations both between and within pigs. The concentration of total fat (Stoldt, 1952) in bile was $0.85 \%$ corresponding to $28 \%$ of dry matter. The influence of endogenous fat and fatty acids originating from bile on digestibility is illustrated with a $40 \mathrm{~kg}$ pig given $1.7 \mathrm{~kg}$ feed daily. Thus, the amount of fat in bile accounted for $23 \%$ of dietary fat, while the quantitatively most important fatty acids made up 2 to $9 \%$ of the corresponding fatty acids in the diet.
\end{abstract}

KEY WORDS: metabolic fat, endogenous fat, bile cannulation

\section{INTRODUCTION}

The main components of bile consist of fat and bile acids which are of importance for digestion and absorption of dietary fat (Holt, 1972; Corring et al., 1979; Clement, 1980; Borgström et al.,1985). Both bile acids and phospholipids play an important role in formation and stabilization of micelles in the digestive tract (Tso et al., 1981). Diacylphosphatidylcholine (lecithin) is the predominant biliary phospholipid (Hay and Carey, 1990). In the digestive tract pancreatic lipase hydrolyzes lecithin to lysophosphatidylcholine (lysolecithin) being a more potent emulgator than lecithin.

The fatty acid composition of bile seems to some extent to depend on the fatty acid composition of the diet (Christensen, 1985; Jenkins et al., 1988). There is 
only scarce information on fatty acid composition of bile from pigs. However, Christie (1973) and Christensen (1985) present values for the fatty acid composition of bile from the gallbladder of pigs.

Investigations of bile secretion in pigs fitted with a cannulae to collect bile have shown a daily secretion from 2-2.5 l(Laplace and Ouaissi, 1977; Juste et al., 1979; Aliev and Khamzatov, 1980; Sambrook, 1981; Juste et al., 1983; Kulig et al., 1989) while an earlier work measured only 11 per $24 \mathrm{~h}$ (Hiby, 1934). The daily secretion of fat with the bile varied from 5-12 $\mathrm{g}$ (review of Juste, 1982).

The aim of the present study was to measure total bile flow in growing pigs as well as the amount and chemical composition of the bile.

\section{MATERIAL AND METHODS}

\section{Cannula design}

The cannulas were modified according to Hee et al. (1985). They were prepared from HTV silicone materials (Wacker-Chemie, München,Germany) as this material can easily be formed (Brandt et al., 1984). After vulcanization in an autoclave $\left(20 \mathrm{~min} ., 130^{\circ} \mathrm{C}\right)$ the cannulas were hardened in an oven $\left(80^{\circ} \mathrm{C}\right)$. To avoid backflow of bile into the cannula two one-way valves were used (Kebo Lab A/S, Ballerup, Denmark).

\section{Animals and cannulation technique}

Ten Danish Landrace female pigs were used for the experiment. Of these pigs seven were used to obtain experience with surgical and collection procedures. However, the last three pigs, in the weight range of $30-55 \mathrm{~kg}$, could be used in several 24 hours total collection of bile. The surgical preparation was the same as used for collection of pancreatic juice (Archambeau et al., 1961; Woods and Foster, 1963; Hee et al., 1985) but modified for bile collection. In pigs the pancreatic and bile duct is separated which allows the preparation of a ,,pouch" for collection of bile.

\section{Diets}

The pigs were fed a traditional pig diet for the growth period $20-55 \mathrm{~kg}$. The composition of the experimental feed is shown in Table 1 and 2.

\section{Experimental procedure}

During bile collection the pigs were placed in metabolic cages to make it easier to handle them. Feeding took place twice a day at 7 and $15 \mathrm{~h}$, respectively, and bile collection started at the morning feeding. The re-entrant cannula was disconnected and a nylon bag $\left(6 \times 25 \mathrm{~cm}\right.$, Sterifol ${ }^{\circledR}$, Buch and Holm A/S, Herlev, Denmark) attached. The nylon bags were changed every hour, and 
TABLE 1

The composition $(\%)$ and chemical content of the diet dry matter $(\%)$

\begin{tabular}{lrlr}
\hline Soya bean meal & 24.0 & Protein & 20.8 \\
Barley & 50.0 & Fat & 4.7 \\
Wheat & 20.4 & Crude fibre & 4.9 \\
Animal fat & 2.0 & Ash & 5.1 \\
Molasses, sugar beet & 1.0 & Starch & 44.2 \\
Dicalcium phosphate & 1.2 & Sugar & 5.8 \\
Calcium carbonate & 0.8 & & \\
Sodium chloride & 0.4 & & \\
Vitamin mixture (1) & 0.2 & & \\
\hline
\end{tabular}

(1) Supplied per kg diet:

400 I.U. A, 1000 I.U. $\mathrm{D}_{3}, 50 \mathrm{mg} \mathrm{E}$ (dl- $x$-tocoferylacetat), $2 \mathrm{mg} \mathrm{K}_{3}, 4 \mathrm{mg} \mathrm{B}, 10 \mathrm{mg}$ D-panthotenic acid, $20 \mu \mathrm{g} \mathrm{B}_{12}$, and $250 \mathrm{mg} \mathrm{FeSO}{ }_{4} \cdot 7 \mathrm{H}_{2} \mathrm{O}, 100 \mathrm{mg} \mathrm{ZnO}, 36 \mathrm{mg} \mathrm{Mn}_{3} \mathrm{O}_{4}, 80 \mathrm{mg} \mathrm{CuSO}{ }_{4} \cdot 5 \mathrm{H}_{2} \mathrm{O}, 260 \mu \mathrm{g}$ $\mathrm{KJ}, 660 \mu \mathrm{g} \mathrm{Na}_{2} \mathrm{SeO}_{3}, 1 \mathrm{~g} \mathrm{CaCO}$.

TABLE 2

Content of fatty acids ( $\mathrm{g} / \mathrm{kg}$ dry matter and $\%$ of total fatty acids) in the basal diet

\begin{tabular}{lccc}
\hline Fatty acids & & $\mathrm{g} / \mathrm{kg}$ dry matter & $\%$ of total fatty acids \\
Lauric acid & $12: 0$ & 0.05 & 1.5 \\
Myristic acid & $14: 0$ & 0.38 & 1.0 \\
Myristoleic acid & $14: 1$ & 0.02 & 0.6 \\
Palmitic acid & $16: 0$ & 10.41 & 28.4 \\
Palmitoleic acid & $16: 1$ & 0.63 & 1.7 \\
Stearic acid & $18: 0$ & 3.13 & 8.6 \\
Oleic acid & $18: 1$ & 10.02 & 27.3 \\
Linoleic acid & $18: 2$ & 10.28 & 27.9 \\
Linolenic acid & $18: 3$ & 0.94 & 2.6 \\
& & & 78.3 \\
Fatty acids, \% of fat & &
\end{tabular}

the amount of bile weighed. Ten per cent was removed for analyses. To minimize the effect on the enterohepatic circulation (Hofmann, 1984) the bile not used for analyses was reintroduced by gravity flow. The bile samples were stored at $-20^{\circ} \mathrm{C}$ until being used.

\section{Analytical methods}

The chemical analyses of the diet were performed according to procedures described by Jakobsen and Weidner (1973). Analyses of the bile were carried out as follows:

Dry matter: $\quad 5 \mathrm{~g}$ bile was dried at $100^{\circ} \mathrm{C}$ to constant weight Ash: ashing at $550^{\circ} \mathrm{C}$ of the dried material from determination of dry matter 
Nitrogen:

Fat:

Fatty acids:

Amino acids:
$5 \mathrm{~g}$ bile was analyzed by the Kjeldahl method using a Kjell-Foss 16200 autoanalyser (Foss Electric A/S, Denmark) determined in $15 \mathrm{~g}$ bile (pooled sample from $24 \mathrm{~h}$ ) according to the Stoldt method (Stoldt, 1952) (extraction with diethyl ether after hydrolysis with $3 \mathrm{~N} \mathrm{HCl}$ ) extraction in $1 \mathrm{ml}$ bile with chloroform: methanol (1:1) (Jenkins et al., 1988). The composition and amount of fatty acid methylesters were measured using gas-liquid chromatography (Rotenberg and Andersen, 1980) amino acid analysis was carried out as described by Mason et al. (1980).

\section{Calculations and statistical procedures}

All calculations and statistical analyses were carried out using the SAS package (SAS, 1985).

\section{RESULTS}

The bile output was measured every hour, but the chemical analyses were performed on pooled samples for 8 hours; denoting: day (800-1500), afternoon (1500-2300), and night (2300-700). There was not found any clear diurnal variations although a drop seemed to occur in the bile output after feeding. The variation in bile output between the three pigs which completed several 24-hours collections was high (Table 3). Especially one pig (no 3) showed a high variation in bile output. This pig not only had a higher bile output, but the concentration of most of the fatty acids in the bile (Table 3) was also higher.

There were no significant differences between the three 8-hour periods. The average values are shown in Table 4 . The amino acid composition of pooled bile samples of the three pigs is shown in Table 5 . As can be seen glycine + alanine and taurine are the dominating amino acids in bile.

\section{DISCUSSION}

In the preliminary investigations more problems than expected were encountered. The common bile duct and sphincter of Oddi in pigs is close to the stomach which makes it difficult to form a pouch. Post-surgical complications were observed in some of the pigs such as low appetite and vomiting due to blockage of the intestinal tract. The recovery of the pigs from surgery, back to normal feeding scale, took one to two weeks and collection of bile could start.

The approach was to establish a cannulation technique for collecting bile of 
TABLE 3

Amount of bile collected and content of dry matter, ash, nitrogen, fat and fatty acids by the individual pig and mean values of three pigs at different time interval

\begin{tabular}{|c|c|c|c|c|c|c|c|c|c|}
\hline Pig no & 1 & 2 & 3 & & Day & Afternoon & Night & & \\
\hline 24-h collections & 5 & 4 & 3 & & & & & & \\
\hline & \multicolumn{4}{|c|}{$\mathrm{g} / 24$ hour } & \multicolumn{4}{|c|}{$\mathrm{g} / 8$ hour } & RMSE $^{1}$ \\
\hline Bile output & $1416^{a}$ & $1661^{a}$ & $2889^{b}$ & $* * *$ & 619 & 620 & 614 & NS & 2) \\
\hline \multicolumn{10}{|l|}{$\%$ of sample } \\
\hline Dry mater & $2.57^{a}$ & $3.52^{b}$ & $3.13^{c}$ & $* *$ & 3.10 & 3.24 & 2.65 & NS & 0.69 \\
\hline Ash & $0.82^{a}$ & $0.88^{b}$ & $0.84^{a b}$ & $*$ & $0.85^{a}$ & $0.87^{a}$ & $0.81^{b}$ & * & 0.06 \\
\hline Nitrogen & 0.083 & 0.095 & 0.087 & NS & $0.091^{a}$ & $0.096^{a}$ & $0.076^{b}$ & $*$ & 0.020 \\
\hline $\mathrm{HCl}-\mathrm{fat}^{3}$ & 0.96 & 0.74 & 0.84 & NS & - & - & - & & 0.16 \\
\hline \multicolumn{10}{|c|}{$\%$ of dry matter } \\
\hline 14:0 & $0.015^{a}$ & $0.017^{a}$ & $0.022^{b}$ & $* * *$ & $0.015^{a}$ & $0.021^{b}$ & $0.017^{a}$ & $* *$ & 0.004 \\
\hline $15: 0$ & 0.023 & 0.028 & 0.034 & NS & 0.025 & 0.028 & 0.029 & NS & 0.009 \\
\hline $16: 0$ & 1.806 & 2.084 & 2.031 & NS & 1.911 & 2.036 & 1.917 & NS & 0.370 \\
\hline $16: 1$ & $0.144^{a}$ & $0.182^{a}$ & $0.214^{b}$ & $*$ & 0.169 & 0.174 & 0.178 & NS & 0.058 \\
\hline $17: 0$ & $0.038^{a}$ & $0.069^{b}$ & $0.100^{c}$ & $* * *$ & 0.060 & 0.066 & 0.064 & NS & 0.016 \\
\hline $17: 1$ & $0.028^{a}$ & $0.049^{b}$ & $0.073^{c}$ & $* * *$ & 0.042 & 0.048 & 0.048 & NS & 0.016 \\
\hline $18: 0$ & $0.638^{a}$ & $0.731^{b}$ & $0.782^{b}$ & $* *$ & 0.719 & 0.718 & 0.664 & NS & 0.094 \\
\hline $18: 1$ & $1.551^{a}$ & $1.685^{\circ}$ & $2.120^{b}$ & $*$ & 1.706 & 1.780 & 1.721 & NS & 0.417 \\
\hline $18: 2$ & $0.964^{a}$ & $1.225^{b}$ & $1.031^{a}$ & $* *$ & 1.080 & 1.095 & 1.007 & NS & 0.215 \\
\hline $18: 3 * 3$ & 0.042 & 0.046 & 0.040 & NS & 0.042 & 0.047 & 0.039 & NS & 0.013 \\
\hline $20: 4$ & $0.417^{a}$ & $0.495^{b}$ & $0.449^{a}$ & $*$ & 0.444 & 0.472 & 0.434 & NS & 0.070 \\
\hline $20: 5$ & $0.067^{a}$ & $0.078^{h}$ & $0.062^{a}$ & $*$ & 0.078 & 0.067 & 0.062 & NS & 0.014 \\
\hline $22: 5^{*} 3$ & $0.050^{a}$ & $0.066^{a b}$ & $0.074^{b}$ & * & 0.066 & 0.050 & 0.074 & NS & 0.019 \\
\hline $22: 6^{*} 3$ & 0.123 & 0.150 & 0.130 & NS & 0.150 & 0.127 & 0.118 & NS & 0.042 \\
\hline
\end{tabular}

1) $\mathrm{RMSE}=$ root mean square error.

2) $\mathrm{RMSE}=665 \mathrm{~g}$ per 24 hour and $222 \mathrm{~g}$ per 8 hour.

3) Analyzed in samples collected for 24 hours.
NS - non significant

$* \mathrm{P} \leqslant 0.05 ;{ }^{* *} \mathrm{P} \leqslant 0.01 ;{ }^{* * *} \mathrm{P} \leqslant 0.001$

$a, b, c-$ means in the same row with different letters differ significantly $(\mathrm{P}<0.05)$

pigs under normal physiological conditions. That means: normal function of the sphincter of Oddi, normal feed intake and the bile cannulae functioning over relatively long periods of time (weeks - months). In spite of the preliminary problems with the surgical technique in establishing the duodenal pouch, it proved possible to carry out collections of bile over several months. Direct cannulation of the bile duct has been used in other experiments (Laplace and Ouaissi, 1977; Sambrook, 1981; Juste et al., 1983; Kulig et al., 1989) assuming that the trauma of direct cannulation was less than that caused by duodenal pouch formation and intestinal anastomosis. However, using direct cannulation of the bile duct is not suitable when investigating over a longer period of time as the direct bile cannulation only works for a short time (Corring, 1980; Sambrook, 1981). 
TABLE 4

Chemical composition and secretion of bile per 24 hours (mean of 3 pigs)

\begin{tabular}{lccc}
\hline & \% of sample & \% of dry matter & $\mathrm{g} / 24$ hour \\
Bile output & & & 1853 \\
& & - & \\
Dry matter & 3.08 & 27.6 & 57.1 \\
Ash & 0.85 & $2.9(17.8)$ & 15.8 \\
Nitrogen $(\mathrm{N} \times 6.25)$ & $0.088(0.55)$ & $1.62(10.2)$ \\
HCl-fat & 0.85 & 27.6 & 15.7 \\
& & & \\
Fatty acids & \% of dry matter & Volume $\%$ & $\mathrm{~g} / 24$ hour \\
& & & \\
$14: 0$ & 0.017 & 0.3 & 0.011 \\
$15: 0$ & 0.028 & 0.4 & 0.017 \\
$16: 0$ & 1.926 & 29.9 & 1.164 \\
$16: 1$ & 0.170 & 2.6 & 0.107 \\
$17: 0$ & 0.063 & 0.9 & 0.044 \\
$17: 1$ & 0.046 & 0.7 & 0.032 \\
$18: 0$ & 0.697 & 10.9 & 0.428 \\
$18: 1$ & 1.718 & 26.4 & 1.095 \\
$18: 2$ & 1.053 & 16.4 & 0.642 \\
$18: 3^{* 3}$ & 0.043 & 0.7 & 0.026 \\
$20: 4$ & 0.453 & 7.1 & 0.265 \\
$20: 5$ & 0.068 & 1.1 & 0.039 \\
$22: 5 * 3$ & 0.062 & 1.0 & 0.033 \\
$22: 6 * 3$ & 0.127 & 2.0 & 0.080 \\
Total fatty acids & 6.550 & & 3.971 \\
\hline & & &
\end{tabular}

The variation in daily bile output from $1.41-2.91$ found in this investigation is within reported values (Laplace and Ouassi, 1977; Juste et al., 1979; Aliev and Khamzatov, 1980; Sambrook 1981, Juste et al., 1983; Kulig et al., 1989; Corring et al., 1990).

In all the reported studies of bile flow including the present one the variation in daily bile output is very high both between pigs and within pigs. This high variation in bile output seems independent of the methods for bile collection i.e. when bile is returned without control of sphincter of Oddi, or bile is returned mimicking the bile flow, or as in the present study returning the bile once per hour.

The fat content of $0.85 \%$ (Table 4 ) is higher than found in investigations by Aliev and Khamzatov (1980) and Sambrook (1981), but these differences could be explained by the applied analytical methods. It is thus found that freezing of bile samples have some disadvantages, as phospholipids may be oxidized and cholesterol may not completely redissolve (Strasberg et al., 1990). Christensen (1985) found a fat content of bile in the gall bladder from $0.67-0.91 \%$. However, 
TABLE 5

Mean values of nitrogen (protein) and amino acids in bile determined in two samples pooled from 3 pigs

$\%$ of dry mtter

Nitrogen $(\mathrm{N} \times 6.25)$

$2.1(13.0)$

Amino acids

$\mathrm{g} / \mathrm{kg}$ dry matter

$\mathrm{g} / 16 \mathrm{~g} \mathrm{~N}$

Glycine + Alanine

51.7

40.8

Taurine

23.9

16.5

Arginine

0.56

0.5

Asparagine

0.89

0.5

Cystine

0.69

0.5

Glutamine

1.85

0.5

Histidine

0.40

0.3

Isoleucine

0.38

0.3

Leucine

0.74

0.6

Lysine

0.76

0.6

Methionine

0.10

Phenylalanine

0.59

0.1

Proline

0.97

0.5

Serine

0.67

0.8

Threonine

0.68

0.5

Tyrosine

0.55

Valine

0.56

0.6

0.4

0.4

Amino acids $\mathrm{N} / 100 \mathrm{~g} \mathrm{~N}$

65.9

it cannot be excluded that the bile in the gall bladder is more concentrated than in the floating bile.

Information on the fatty acid composition of the fat in bile is scarce, but the values in the present study (Tables 3 and 4) are in accordance with other values of bile sampled in the gallbladder (Christensen 1985), whereas Christie (1973) found higher contents of palmitic and linoleic acids. Furthermore, Christensen (1985) showed that the fatty acid composition of bile correlates to dietary fatty acids. A decreasing content of dietary linoleic acid (18:2) caused a decrease in both bile and plasma concentration of $18: 2$. Similar findings were shown with preruminant calves (Jenkins et al., 1988).

In the present study the content of nitrogen $(\mathrm{N})$ in bile of $0.088 \%$ or $2.9 \%$ in bile DM (Table 4) is close to values reported by Sambrook (1981) and Corring et al. (1990). When assuming $16 \% \mathrm{~N}$ in protein $0.088 \% \mathrm{~N}$ corresponds to $0.55 \%$ protein which is close to other values found in the bile sampled from the gallbladder (Godfrey et al., 1981). The protein in bile originates mainly from plasma 
where bile is an important excretion route for immunoglobulins and plasma proteins (Godfrey et al., 1981; LaRusso, 1984; Mullock et al., 1985; Coleman, 1987).

The amino acid analysis (Table 5) showed that glycine + alanine (they could not be separated) and taurine contributed to more than half of the amounts of amino acids. Before bile acids are secreted from the liver they are conjugated with an amino acid (Hofmann, 1984) normally glycine and taurine. The distribution between glycine and taurine depends on animal species, but in pigs most of the bile acids are conjugated with glycine (Haslewood, 1971) which is in agreement with the observations made in this study.

The contribution to the secretion of endogenous fat and some fatty acids in bile is estimated for a $40 \mathrm{~kg}$ pig receiving $1.7 \mathrm{~kg}$ diet of identical composition as the diet in Table 1. The estimates are shown in Table 6 . The estimated amounts of endogenous fat and fatty acids at terminal ileum and faeces are obtained from previous studies on pigs given graded levels of soya bean oil to a low fat diet (Jørgensen et al., 1992b).

TABLE 6

Estimation of endogenous fat and fatty acids for a pig of $40 \mathrm{~kg}$ liveweight, receiving $1.7 \mathrm{~kg}$ of diet daily

\begin{tabular}{|c|c|c|c|c|c|c|c|}
\hline & \multirow{3}{*}{$\begin{array}{c}\text { Diet } \\
\mathrm{g}\end{array}$} & \multicolumn{6}{|c|}{ Endogenous } \\
\hline & & \multicolumn{2}{|c|}{ Bile $^{\text {Jl }}$} & \multicolumn{2}{|c|}{ lleum ${ }^{2 y}$} & \multicolumn{2}{|c|}{ Faeces $^{3 /}$} \\
\hline & & $\mathrm{g}$ & $\%^{3 \prime}$ & g & $\%^{3+}$ & g & $\%^{3)}$ \\
\hline Fat- $\mathrm{HCl}$ & 67.9 & 15.7 & 23.1 & 6.9 & 10.2 & 6.4 & 9.4 . \\
\hline $16: 0$ & 15.0 & 1.2 & 8.0 & 0.3 & 2.0 & 0.6 & 4.0 \\
\hline $18: 0$ & 4.5 & 0.4 & 8.9 & 0.1 & 2.2 & 0.3 & 6.7 \\
\hline $18: 1$ & 14.5 & 1.1 & 7.6 & 0.2 & 1.4 & 0.1 & 0.7 \\
\hline $18: 2$ & 14.9 & 0.6 & 4.0 & 0.1 & 0.7 & 0.04 & 0.3 \\
\hline $18: 3$ & 1.4 & 0.03 & 2.1 & 0.03 & 2.1 & 0.04 & 2.9 \\
\hline $20: 4$ & - & 0.3 & - & - & - & - & - \\
\hline
\end{tabular}

1) Present study.

2) Ileal and faecal values of endogenous fat and fatty acids from Jørgensen et al. (1992b).

3) Per cent of dietary amount.

The total amount of endogenous fat excreted contributed significantly to the duodenal digesta $(23 \%)$ in relation to the dietary amount of fat. The levels of endogenous biliary fatty acids in relation to dietary fatty acids are low and contribute to only $2-9 \%$ of dietary fatty acids.

Assuming the amounts of endogenous fat and fatty acids at the terminal ileum are as shown in Table 6, a significant reabsorption of fat and fatty acids have taken place in the small intestine. Furthermore biliary fat and fatty acids are not the only source of endogenous fat as desquamation of mucosa cells and 
exudation also occur (Clement, 1980). The estimated amount of endogenous total fat is not different at the terminal ileum and in faeces (Table 6) but as a result of the microbial activity in the hind-gut the ratio between saturated and unsaturated fatty acids changes to a great extent from ileum to faeces (Bayley and Lewis, 1965; Just et al., 1980; Jørgensen et al., 1992a).

In conclusion, the present study shows that bile cannulated pigs using the pouch technique had a daily bile output of 1.81 with a total amount of lipids of $16 \mathrm{~g}$ and a total amount of long chain fatty acids of $4 \mathrm{~g}$. The main fatty acids were in per cent of total fatty acids: $16: 0(30 \%), 18: 1(26 \%), 18: 2(16 \%), 18: 0(11 \%)$ and $20: 4(7 \%)$.

\section{REFERENCES}

Aliev A.A., Khamzatov Zh. Z., 1980. Bile secretion in young pigs in relation to lipid nutrition. Dokl. Vses. Akad. Skh. Nauk. Im. V. I. Lenina, 2, 29-31

Archambeau J., Greenlee H., Harber P., 1961. A modified total pancreatic fistula. Proc. Soc. Exp. Biol. Med. 107, 986-987

Bayley H.S., Lewis D., 1965. The use of fats in pig feeding. I. Pig faecal fat not of dietary origin. J. Agric. Sci. 64, 367-372

Borgström B., Barowman J.A., Lindström M., 1985. Roles of bile acids in intestinal lipids digestion and absorption. In $\mathrm{H}$. Daniclson and J. Sjövall (Editors), Sterols and Bile Acids. Amsterdam: Elsevier Science Publishers B.V. pp. 405-425.

Brandt M., Süfke A., Assumus G., 1984. Fistulierung von Milchkühen im Duodenum und Ileum mit einer neuartigen Umleitungskanüle aus Silikon. Kurzfassungen der Vorträge zur 38. Tagung vom 28. bis 30. März 1984 in Göttingen. Gesellschaft für Ernährungsphysiologie der Haustiere 38. Tagung, 61-62

Christensen K., 1985. Determination of linoleic acid requirements in slaughter pigs. 577. Report from the National Institute of Animal Science, Denmark pp. 158.

Christie W.W., 1973. The structure of bile phosphatidylcholines. Biochim. Biophys. Acta, 316, 204-211

Clément I., 1980. Intestinal absorption of triglycerols. Repr. Nutr. Dévelop. 20, 1285-1307

Coleman R., 1987. Biochemistry of bile secretion. Biochem. J. 244, 249-261

Corring T., 1980. Endogenous secretions in the pig. In A. G. Low and I. G. Partridge (editors), Current Concepts of Digestion abd Absorption in Pigs. NIRD-HRI. Reading: The National Institute for Research in Dairying, pp. 136-150.

Corring T., Juste C., Simoes-Nunes C. and Bourdon D., 1979. Effet de la sécrétion biliaire sur la digestion chez le porc. Ann. Biol. Bioch. Biophys. 19, 1123-1130

Corring T., Soufrant W. B., Darcy-Vrillon B., Gebhardt G., Laplace J.P., Rerat A., 1990. Exogenous and endogenous contribution to nitrogen fluxes in the digestive tract of pigs fed a casein diet. 1. Contributions of nitrogen from the exocrine pancreatic secretion and the bile. Reprod. Nutr. Dévelop. 30, 717-722

Godfrey P.P., Warner M.J., Coleman R., 1981. Enzymes and proteins in bile. Biochem. J. 196, 11-16 Haslewood G.A.D., 1971. Bile salts of germ - free domestic fowl and pigs. Biochem. J. 123, 15-18 Hay D.W., Carey M.C., 1990.Chemical species of lipids in bilc. Hepatology 12, 6S-16S

Hee J., Sauer W.C., Berzins R., Ozimek L., 1985. Permanent re-entrant diversion of porcine pancreatic secretions. Can. J. Anim. Sci. 65, 451-457 
Hiby F., 1934. Untersuchungen über die Gallensekretion des Schweines. (Thesis). Hannover: Tieräztliche Hochschule Hannover, pp. 35.

Hofmann A.F., 1984. Chemistry and enterohepatic circulation of bile acids. Hepatology, 4, 4S-14S Holt P.R., 1972. The role of bile acids during the process of normal fat and cholesterol absorption. Arch. Intern. Med. 130, 574-583

Jakobsen P.E., Weidner K., 1973. In Chemistry of Feedstuffs and Animals. Compendium 1, Vet., Faculty FAO Fellows. Royal Vet. Agric. Univ., Copenhagen, pp. 14-55

Jenkins K.J., Griffith I., Hidiroglou M., Kramer J.K.G., 1988. Bile acids and lipids in gall bladder bile of the preruminant calf. Nutr. Report. Intern. 37, 703-712

Jørgensen H., Jakobsen K., Eggum B.O., 1992a. The influence of different protein, fat and mineral levels on the digestibility of fat and fatty acids measured at the terminal ileum and in faeces of growing pigs. Acta Agric. Scand. Scct. A, Anim. Sci. 42, 177-184

Jørgensen H., Jakobsen K., Eggum B.O., 1992b. Endogenous fat and fatty acids at the terminal ileum and in faeces in growing pigs. Acta Agric. Scand. Sect. A, Anim. Sci. (in press)

Just A., Andersen J.O., Jørgensen H., 1980. The influence of diet composition on the apparent digestibility of crude fat and fatty acids at the terminal ileum and overall in pigs. Z. Tierphysiol. Tierernähr. Futterminttelkde. 44, 82-92

Juste C., 1982. Apports endogenes par les secretions digestives chez le porc. In J.P. Laplace, T. Corring and A. Rerat (editors), Digestive physiology in the pig. Les Colloques de l'INRA, no 12, Paris: Institut National de la Recherche Agronomique, pp. 155-173

Juste C., Corring T., Breant P., 1979. Excrétion biliarie chez le porc: niveau et résponse au repas. Ann. Biol. Anim. Bioch. Biophys. 19, 79-90

Juste C., Demarne Y., Corring T., 1983. Response of bile flow, biliary lipids and bile acid pool in the pig to quantitative variations in dietary fat. J. Nutr. 113, 1691-1701

Kulig W., Kirchgessner M., Erhardt W., Schliak M., Ascherl R., 1989. Zur Messung von Galleflussrate und Gallelipiden an gallengangskanülierten Schweinen mittels einer vollautomatischen Rückführapparatur. J. Anim. Physiol. Anim. Nutr. 62, 93-100

Laplace J.-P., Ouaissi M. A., 1977. L'excrétion biliaire chez le porc. Influence des repas et role éventuel de récepteurs oddiend dans le controle du débit cholédocien. Ann. Zootech. 26, 595-613

LaRusso N.F., 1984. Proteins in bile: how they get there and what they do. Amer. J. Physiol. 247, G199-G205

Mason V.C., Bech-Andersen S., Rudemo M., 1980. Hydrolysate preparation for amino acid determinations in feed constituents. 8. Studies of oxidation conditions for streamlined procedures. Z.Tierphysiol. Tierernähr.Futtermittelkde. 43, 146-164

Mullock B.M., Shaw L.J., Fitzharris B., Peppard J., Hamilton M.J.R., Simpson M.T., Hunt T.M., . Hinton R.H., 1985. Sources of proteins in human bile. Gut 26, 500-509

Rotenberg S., Andersen J.O., 1980. The effect of dietry citrus pectin on fatty acid balance and the fatty acid content of the liver and small intestine in rats. Acta Agric. Scand. 30, 8-12

Sambrook I.E., 1981. Studies on the flow and composition of bile in growing pigs. J. Sci. Food Agric. $32,781-791$

SAS., 1985. SAS User's Guide: Statistics. (Version 5 Edition). SAS Institute Inc., Box 8000, Cary, NC 27511. pp. 956

Stoldt W., 1952. Vorschlag zur Vereinheitlichung der Fettbestimmung in Lebensmitteln. Fette und Seifen, 54, 206-207

Strasberg S.M., Harvey P., Hofmann A.F., 1990. Bile sampling, processing and analysis in clinical studies. Hepatology 12, 176S-182S

Tso P., Kendrick H., Balint J.A., Simmonds W.J., 1981. Role of biliary phosphatidylcholine in the absorption and transport of dietary triolein in the rat. Gastroenterology, 80, 60-65

Woods L.P., Foster J.H., 1963. Chronic pancreatic fistula - A new experimental technique. J. Surg. Res. 3, 9-11 


\section{STRESZCZENIE}

\section{Wydzielanie tluszczu i kwasów tluszczowych z żólcią u rosnących świń}

Celem pracy było zbadanie udziału żólci w endogennym wydzielaniu ze szczególnym uwzględnieniem ilości tłuszczu i długo-łańcuchowych kwasów tluszczowych. W doświadczeniu wstępnym opracowano metodę zakladania przetoki mostkowej do woreczka utworzonego z cześci dwunastnicy do której uchodzi przewód żółciowy i do dwunastnicy. Doświadczenie właściwe przeprowadzono na 3 przetokowanych loszkach o początkowej masie ciała $30 \mathrm{~kg}$ żywionych konwencjonalną mieszanką zawierającą $20,8 \%$ białka i $4,7 \%$ tłuszczu w suchej masic. Wyplywającą z przetoki żółć micrzono co godzinę, pobierano $10 \%$ próby i resztę podawano do dwunastnicy. Średnia dzienna objętość żółci wynosiła 1,81. Stężenie tłuszczu ogólnego w żółci, oznaczonego metodą Stoldta, wynosiło 0,85\%, co stanowiło $28 \%$ suchej masy źólci. Średnio na dobę wydzielalo się z żółcią $16 \mathrm{~g}$ thuszczu i $4 \mathrm{~g}$ długo-łańcuchowych kwasów tłuszczowych. Udział głównych kwasów thuszczowych w ogólnej ilości thuszczu wynosił: $16: 0-30 \%, 18: 1-26 \%, 18: 2-16 \%, 18: 0-11 \%$ i $20: 4-7 \%$. Ilość tłuszczu wydzielonego w żółci stanowiła $23 \%$ tłuszczu podanego w dawce, natomiast ilościowo najważniejsze kwasy tłuszczowe stanowily $2-9 \%$ kwasów tłuszcrowych dawki. Dobowa ilość N wynosila 1,62g. Glicyna, alanina i tauryna stanowiły $57 \%$ bialka ogólnego. 